\title{
Jewish archives and sources in the Nordic countries
}

\section{The current state of affairs and future prospects}

\author{
Sofie Lene Bak, Vibeke Kieding Banik, Bjarke Følner, \\ Simo Muir, Dóra Pataricza and Pontus Rudberg
}

DOI: https://doi.org/10.30752/nj.111889

AbSTRACT - This article aims to give an overview of Jewish archives and archival sources in Denmark, Finland, Norway and Sweden. Besides describing significant existing collections, the article looks into ongoing archival projects and digitising and infrastructure programmes, and maps out future challenges.

\section{Introduction}

At 2 o'clock on the afternoon of Sunday, 22 October I944, a meeting took place at the home of Rabbi Marcus Ehrenpreis in Stockholm. Present at the meeting were several Jewish activists from the Nordic countries. ${ }^{1}$ The main question for the meeting to discuss was whether the Nordic countries should join the World Jewish Congress (WJC), and in that case, should they do so as one Nordic section or separately?

1 Present at the meeting were Marcus Ehrenpreis, Salomon Adler-Rudel, Elizier Berlinger, Mendel Bernstein, Joseph Ettlinger, Arthur Henriques, C. B. Henriques, Norbert Masur, Samuel Nisell, Iser Salomonsson, Binjamin Slor, Gilel Storch, Leo Wainstein, Hugo Valentin, Erik Wolff and Herbert Friedländer. Riksarkivet (National Archives of Sweden), Judiska församlingens arkiv, Huvudserien, F i 9: I, World Jewish Congress, Svenska Sektionen, 'Protokoll nr I fört vid sammanträde hos prof. Ehrenpreis Söndagen den 22/IO I 944 kl. I4'.
In the meeting, some of the participants from Norway and Denmark emphasised that officially joining the congress at that time, while their countries were occupied by Nazi Germany and members of their communities were held hostage, would be dangerous. The Finnish Jewish delegate, Leo Wainstein, on the other hand, declared that all the Jews of Finland, without any reservations, had already, by democratic procedure, decided to join a Nordic section of the World Jewish Congress, to do whatever could be done to help the Jews of Europe. However, since the Norwegian and Danish communities were not able to join the congress at the time, it would be misleading to call it a Nordic section, their delegates stressed. Without Norway and Denmark, it would only be 'half-Nordic', in the words of one of the Danish representatives, C. B. Henriques. Consequently, the delegates agreed that two separate sections would be formed for the time being: one Swedish and one Finnish, 
and that the Norwegian and Danish Jews would join the congress after the war.

The protocol of the meeting in Ehrenpreis's apartment is an essential source of Jewish history in each of the Nordic countries, as it can tell us something about the view on the work of the congress, Zionism, the organisation of post-war relief and the idea of a world Jewry in the different Nordic countries. However, it also shows that to uncover the sources of Jewish history in each of the Nordic countries, we must also search in the archives in the other Nordic countries. In this case, the meeting protocol is preserved in the archives of the Jewish Community in Stockholm, but to understand the contexts of the delegates' statements, we may have to use sources from each one of the Nordic countries.

Besides, as Vibeke Banik's and Laura Ekholm's research (2019) has shown, although the history of the Jews in the Nordic countries shows significant differences between the countries in patterns of chain migration, business and family life, it is also an integrated, or at least interconnected, history. Familiarity with archival collections in each country and having access to them is essential for such research.

This article aims to give an overview of Jewish archives and archival sources in Denmark, Finland, Norway and Sweden. Besides describing significant existing collections in the Nordic countries, the article looks into ongoing archival projects, and digitising and infrastructure programmes. We will describe each country separately, after which we discuss common challenges. The article does not intend to be a complete survey; the authors present only a selection of the most important archives. Owing to limitations of length, not all literature concerning the archives has been included.

\section{Denmark}

The first Jewish immigrants arrived in the kingdom of Denmark in the seventeenth century. They were of Sephardic origin and were invited by King Christian IV. Later, Ashkenazi Jews from the German principalities followed. In the late nineteenth and early twentieth century, a new wave of Jewish immigrants came to Denmark as part of the mass migration of Jews from tsarist Russia and other parts of Eastern Europe. In more recent times, about 3,000 Jews fled to Denmark from communist Poland in the late i 960 and early i97os.

Various archives document four centuries of Danish Jewish history on a national and local level, recording conflicts and reluctance as well as co-existence and acculturation.

The main Jewish archives and collections in Denmark are the archive of the Jewish Community in the Danish National Archives, the Judaica and David Simonsen Collections of the Royal Danish Library and the collection of the Danish Jewish Museum. Only selected parts of these archives and collections have been digitised and are available online.

A comprehensive database of Danish Jewish families and a photographic database of Jewish gravestones are available as significant supplementary online resources. Another supplementary online resource gives online access to the arrival protocols of the refugees who fled to Sweden due to the Nazi action against the Danish Jews in 1943 .

Apart from the collections, archives and online resources with specific Jewish relevance or origin, it is also important to highlight that many important archival sources related to the lives and living conditions of Jews in Denmark are to be found in other Danish archives and collections. Similarly, it is essential to emphasise the relevance of 
archival sources and material that shed light on gentile conceptions of Jews and the historical relationship between Christians and Jews in Denmark more broadly. In Denmark and many other countries, conceptions of Jews and anti-Jewish sentiment preceded the arrival and presence of actual Jews by several hundred years. Likewise, a guide to relevant archival sources should also include references for historians and researchers looking for sources on the character and history of antisemitism in Denmark. This section provides a short overview of the most important collections, archives and online resources.

\section{The archive of the Jewish Community}

The archive of the main Jewish Community (Det jødiske samfund i Danmark) at the Danish National Archives (Rigsarkivet) contains records from the main congregation in Copenhagen and from the former Jewish congregations in Aalborg, Aarhus, Assens, Fredericia, Faaborg, Hillerød, Horsens, Nakskov, Nyborg, Odense, Randers, Svendborg, Vejle and Viborg. In addition, it includes the archives of many different associations and institutions and several prominent Jewish persons within the community.

Unfortunately, much of the early part of the archive was destroyed during the Copenhagen fire of 1795 and the bombardment of Copenhagen in 1807. Thus, most of the sources in the archive cover the period from the beginning of the nineteenth century onwards, whereas the period before 1807 is only fragmentarily documented.

A guide to the archive was published in r993 (Svenstrup and Helk r 993) and still functions as a useful resource. The archive can be searched via the Daisy search engine provided by the Danish National Archives. A few selected documents have been digitised and are available online through
Arkivalieronline database - notably the records of births and deaths in most Jewish congregations that have existed in Denmark.

\section{The Judaica Collection}

and the David Simonsen Collections of the Royal Danish Library

The Judaica Collection at the Royal Danish Library (Det Kgl. Bibliotek) in Copenhagen is a rich collection of manuscripts and printed works in Hebrew and Yiddish and additional materials written in Ladino, Judaeo-Arabic and other Jewish languages. The collection also includes a smaller collection of pre- $195^{\circ}$ publications in Western languages.

All items in the Judaica Collection (approximately 36,500 catalogue records as of June 201 8) are registered in the Royal Danish Library online catalogue. All items can be searched for in transcription, and large parts of the collection can also be searched using Hebrew script (Jansson 201 8a).

In I932, the Royal Danish Library acquired the extensive private library and archives of the professor and rabbi David Simonsen (I853-I932). Simonsen's private library comprises approximately 25 ,000 printed volumes on Jewish topics, written in Hebrew, Yiddish and Western languages. The collection survived the Second World War unharmed and contains several rare works that are known to exist in only a few copies. The collection also contains approximately I90 manuscript volumes and a collection of Simonsen's private letters, most of which are available in facsimile copies (Jansson 20I 8b).

\section{The collection of the Danish Jewish Museum}

The collection of objects for the Danish Jewish Museum (Dansk Jødisk Museum) began in I 985 with the creation of the Foundation for the Danish Jewish Museum (Fonden for 
Dansk Jødisk Museum). An essential part of the background was the success of several exhibitions held in 1983 and r 984 to commemorate the fortieth anniversary of the rescue of the Danish Jews and the 3ooth anniversary of the Jewish Community. These exhibitions generated much interest and showed potential to create a more permanent Jewish museum in Denmark. Since then, the collection has grown steadily and currently includes nearly 8,000 objects, photos, recordings and works of art, and archival material related to more than 900 different Danish Jewish individuals, associations, corporations and institutions.

The collection primarily contains items donated by individuals and from more minor Jewish associations and businesses. As such, the collection inspires research on the history of specific Jewish persons, associations and businesses and memorate studies. In addition, the collection contains several larger donations from the Jewish Community in Denmark, including a unique donation of more than 300 ritual objects (Følner 20II). The best-known part of this donation is probably the well-preserved collection of just over 200 Danish Torah binders dating from the early eighteenth to the early twentieth century.

Together, the items in the Danish Jewish Museum collection shed light on a broad range of religious, cultural, artistic and political topics about the history of Jews in Denmark - and often from a personal angle. The collection thus reflects many different

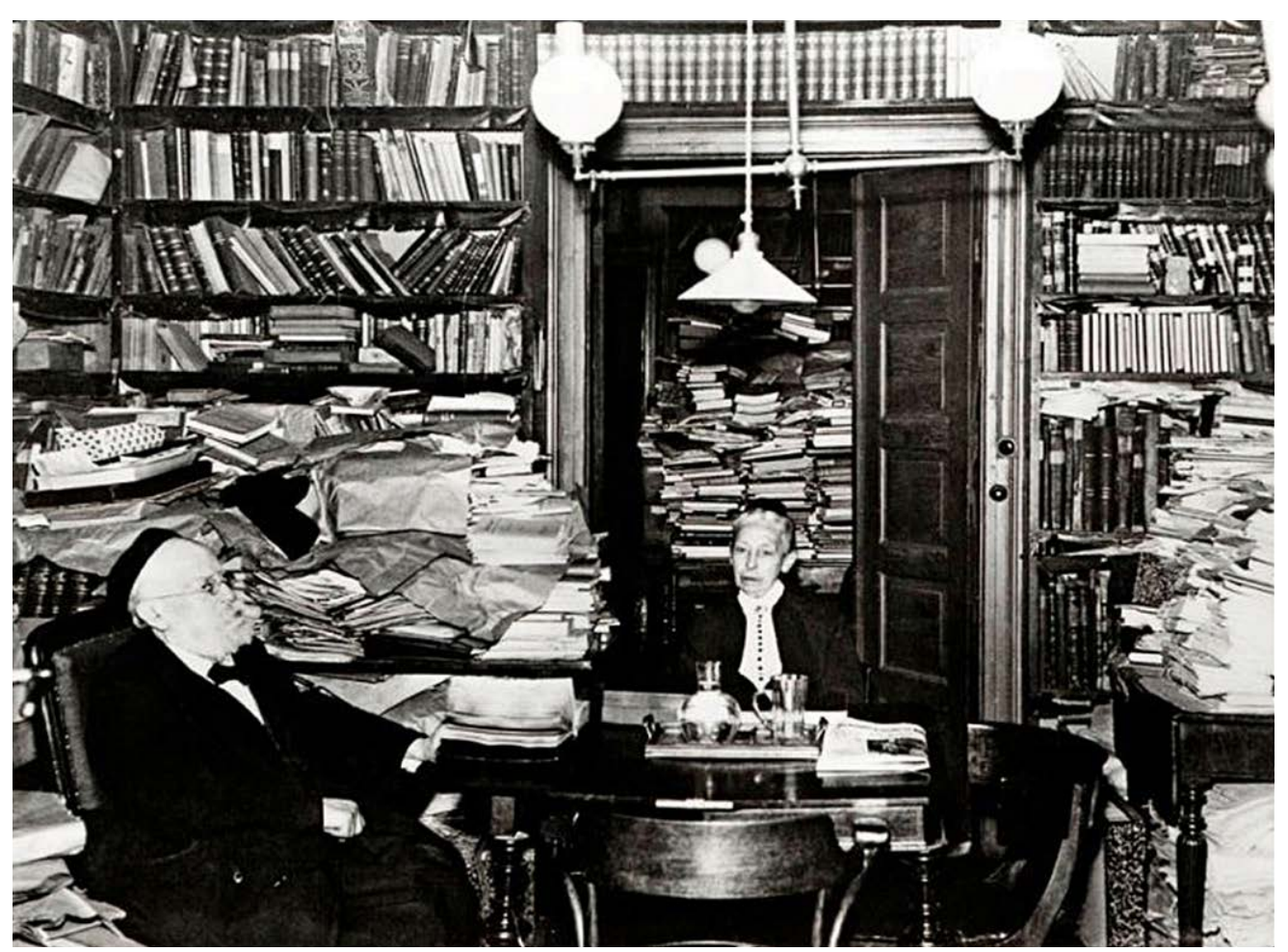

Fig. 1. Professor and rabbi David Simonsen (1853-1932) and his wife Cora surrounded by books in their apartment in Skindergade 28 in Copenhagen. The photo was taken around 1930, shortly before the Simonsen couple had to buy an extra apartment in the same stairway to provide space to live in. According to hearsay, even the building itself suffered from the weight of all the books. In 1932, the Royal Danish Library acquired Simonsen's extensive private library and archives. Photo courtesy of the Royal Danish Library. 
conceptions of what it means to be Jewish and what it means to be Danish - and as such provides an empirical basis for studies in processes of identity, integration and acculturation.

From 2007 to 20I I, the Danish Jewish Museum conducted a research and collection project titled 'Wartime Experiences of the Danish Jews I 943-5'. This resulted in the collection of more than a hundred interviews, over seventy-five three-dimensional objects, archival material from over two hundred individuals, and several films and digitised objects, including photo albums and diaries. The project also resulted in many new findings regarding the flight of the Danish Jews in 1943 (Bak 20 I I).

Most of the items in the collection of the Danish Jewish Museum have been registered and are searchable via the online portals Museernes Samlinger and Kunstindeks Danmark.

In more recent years, the museum has collaborated with the Danish Institute for International Studies (Dansk Institut for Internationale Studier) to digitise and publish more than 6,00o Swedish refugee protocols detailing the circumstances of the Danish Jewish refugees who arrived in Sweden in October 1943 and beyond. The digitised protocols are searchable and available online in the Safe Haven database.

\section{The Danish-Jewish Genealogical Database and the photographic database of Jewish funerals}

The Danish Jewish Genealogical Database is an essential digital resource, which attempts to encompass all Danish Jewish families. At present, the database comprises more than ro9,000 individuals, and it is continually expanded and maintained by dedicated volunteers. A supplementary photographic database, Danish Jewish Funerals and Tombstones I886, covers Jewish funerals in Denmark until i 886. This database comprises more than 6,000 photographs of Jewish tombstones in Denmark.

\section{Relevant sources in other archives}

Apart from the specific Jewish collections and archives, relevant material can also be found in several other archives, including the archives of the Danish Chancellery (Danske Kancelli), the Ministry for Education and Church Affairs (Kulturministeriet), the Danish Police (Politiet i Danmark), and of different Danish and German authorities (i.e. during the Second World War) (all in Danish National Archives) as well as in local and regional archives.

By way of example, work is currently being carried out to identify Danish Jews among the so-called 'petition protocols' (supplikprotokoller) in the archive of the Danish Chancellery, which have been made available on the 'Arkivalieronline' database. The archive contains an unbroken record of all applications and petitions sent from Danish citizens to the King via the Danish Chancellery in the eighteenth century, and it is currently estimated that Danish Jews may have sent somewhere between 2,00o and 4,000 of these applications and petitions.

\section{The Second World War and the Holocaust}

Apart from the online protocols, mentioned above, on Danish Jews upon their arrival in Sweden in 1943 and the rich sources of the Danish Jewish Museum, the archives of the Museum of Danish Resistance (Fridhedsmuseet) contain materials and objects on Danish deportees to Theresienstadt during the Holocaust. In addition, the online photo archive of the museum contains more 
than 60,000 pictures with free download. Far from relating exclusively to the resistance, the collection depicts, for example, the daily lives of the Danes during the war and post-war commemoration and contains most of the rare photographs relating to the flight of the Danish Jews in October I 943.

An essential supplement to the oral testimonies collected by the Danish Jewish Museum is 123 testimonies from the USC Shoah Foundation Institute, available at the museum as a Visual History Collection site. The selected testimonies all have a relation to Denmark. Currently, efforts are being made to add metadata to the index of the interviews relating to Denmark at the Shoah Foundation's online catalogue 'Visual History Archive'. In addition, the National Archives holds a collection of testimonies documenting the escape to Sweden in r $943 .{ }^{2}$ The life and destiny of Jewish refugees from Germany and Central Europe who sought political asylum in Denmark in the I 93 os trying to escape Nazi persecution is documented by case files in the archives of the National Commissioner of Danish Police, Inspection of Foreigners (Rigspolitichefen, Tilsynet med udlændinge) at the National Archives. Only approximately 2,000 Jewish refugees were granted residence permits in Denmark before the Second World War (Rünitz 2000, 2005).

The Danish Refugee Administration in Sweden (Dansk Flygtningehjælp i Sverige), located at the Embassy of Denmark in Stockholm, was established to handle the growing number of Danish refugees in Sweden during the war. The archive of the administration, available at the National Archives in Copenhagen, comprehensively

2 Rigsarkivet (Danish National Archives) Manuscript Collection, IV, T48 O. Barfoed, korrespondance og beretninger. documents the exile in Sweden and contains a complete registry of all Danish refugees in Sweden during the war. In addition, the archives contain sources on the refugee camps (forlogninger) in Sweden, financial aid, social services and repatriation. Approximately 8,000 of the 20,000 Danish refugees in Sweden during the war were of Jewish descent.

As to post-war restitution, the archives of the Restitution Council (Erstatningsrådet) and the Directorate for Accident Insurance (Direktoratet for Ulykkesforsikringen) in the National Archives contain more than I,200 applications for restitution and invalidity pensions from Danish Jewish families and is an excellent source to the material and emotional consequences of exile and deportation (Bak 20I2).

\section{Sources on conceptions of Jews} and antisemitism in Denmark

For the period from the Middle Ages until the twentieth century, the impressive works of the church historian Martin Schwarz Lausten (Lausten I 992, 2000, 2002, 2005, $2007 \mathrm{a}, 2007 \mathrm{~b})$ provide a comprehensive overview of relevant sources that shed light on the perception of Jews and the relationship between Christians and Jews in Denmark.

Archives of antisemitic and National Socialist organisations such as the Danish Anti-Jewish League (Dansk Antijødisk Liga) and the National Socialist Workers' Party of Denmark (Danmarks Nationalsocialistiske Arbejderparti, DNSAP) are held by the Danish National Archives. Materials on neoNazi and far-right organisations are available at the Labour Movement Library and Archives (Arbejderbevægelsens Bibliotek \& Arkiv). 


\section{Finland}

The first Jews arrived in Finland when the territory was still part of Sweden (1362-I 809), and they could only settle down if they converted. Finland became a part of the Russian Empire in I809, and after 1827 Jewish soldiers (including the so-called Cantonists, who had been conscripted as children) were the first Jews to reside in the territory. According to the decree of 1858 , discharged Russian soldiers and their families were allowed to stay temporarily in Finland regardless of their religion. The decree of I 869 regulated occupations open to Jews, mainly limited to clothing and other hand-made materials at the marketplace (Ekholm 20I3; Harviainen I 998; Muir 2004). Jews were granted full civil rights when Finland gained independence in 1917, and in 1922, the Freedom of Religion Act (Uskonnonvapauslaki) secured their rights as a religious community. Currently, around I,300 registered Jews belong to the Helsinki and Turku Jewish communities, including members living abroad.

The main Jewish archives and collections in Finland are the archive of the Jewish Community, located partly at the community and in the National Archives of Finland and the National Library of Finland. As with other Nordic countries, only selected parts of these archives and collections have been digitised and are available online. Finland has recently taken part in international networks, such as the European Holocaust Research Infrastructure (EHRI) and Yerusha: European Jewish Archives Portal.

\section{Jewish collection in the National Archives}

The core of the historical archives of the Jewish communities in Finland is in the National Archives of Finland (Kansallisarkisto / Riksarkivet) in Helsinki and Turku. In the mid-I99os, the Jewish Community of Helsinki deposited its collections in the National Archives, and they were opened to the public in 1998 under the name Finnish Jewish Archives (Suomen juutalaisten arkisto) (Helsingin Sanomat 1998). ${ }^{3}$ Besides documents on the administration of the community, the records hold material from traditional religious societies, like Hevra Kadisha and Bikur Holim, from Jewish cultural and sports associations, like the Jewish Choir Association (Juutalainen Laulukuoro ry) and Makkabi, to Zionist organisations like WIZO and Keren Kajemet le-Israel. The oldest documents in the collection are the pinkasim, register books of the religious societies, the pinkas Hevra Kadisha dating back to I864. The linguistic variety of the documents is broad, ranging from Yiddish and Hebrew to Russian, Swedish and Finnish.

The Finnish Jewish Archives hold, besides archives of the Jewish Community of Helsinki, some documents from the historic communities of Vyborg and Tampere. Most of the archives of the Jewish Community of Vyborg went missing during the Second World War and after the Soviets annexed Karelia. Smaller historic communities like the ones in Hämeenlinna and Hamina have not left behind any known archives. However, records of Russian military officials held in the National Archives contain documents concerning the history of Jewish soldiers and their families and the subsequent communities during the Grand Duchy of Finland (1809-I9I7). The still existing Jewish Community of Turku deposited its records with the regional division of the National Archives in Turku in 2008.

3 The Finnish Jewish Archives has been for the most part catalogued under several grants from the Leo and Regina Wainstein Foundation (Finnish Cultural Foundation). 
During the renovation of the Helsinki synagogue in 2005-6, significant additions to the Finnish Jewish Archives were made. Also, a cellar of forgotten archival documents was discovered in a building on Uudenmaankatu street owned by the Jewish Community. At this point, the vast photo collection of the archives was catalogued (Muir 2005: 23). With approximately ro,ooo photos, the collection contains images of individuals and families and photos of cultural and social life, and visits of political figures to the communities, synagogues and cemeteries. In 20 ro the National Archives and the Jewish Community of Helsinki ran a project to increase the number of Jewish private collections in the National Archives. As a result, over ten private archives of Jewish cultural personalities and other members of the Jewish communities were donated to the National Archives (Muir 2010: 30; Muir 201 I: 30).

Currently, file descriptions of the Finnish Jewish Archives (comprising 30 linear metres), the Archives of the Jewish Community of Turku (Turun juutalaisen seurakunnan arkisto, comprising 8 linear metres), and the various private archives are available in the 'Astia' online service (Astia 202 I) of the National Archives. Some parts, for instance, minutes of the Jewish Community of Helsinki and the archive of the Jewish Refugee Committee (Judiska Flyktingskommittén, founded I 938), have been digitised and are available in Digitaaliarkisto, the portal of digital resources of the National Archives (Digitaaliarkisto $202 \mathrm{I}) .{ }^{4}$ To access the Finnish Jewish

4 The United States Holocaust Memorial Museum (USHMM) holds material from the Finnish Jewish archives related to the history of the Holocaust in a digitised form (USHMM 202I). These are freely available on site and contain correspondence of the Jewish Community of Helsinki, primarily concerning aid to Jewish refugees and
Archives, one needs to obtain permission from the Director General of the National Archives, and for specific parts with sensitive and confidential information, also additional permission from the Jewish Community of Helsinki. To access the Archives of the Jewish Community of Turku, permission from the Jewish Community of Turku is required.

The National Archives also holds other collections that are relevant when studying the history of Jews in Finland. The records of the Office of the General Governor (Kenraalikuvernöörin kanslia), the Russian Military Archives (Venäläiset sotilasasiakirjat), the Helsinki Police Passport Office (Helsingin poliisin passitoimisto), to name a few, are an essential source when researching the life of Jewish soldiers in the Russian military and the families that settled in the country during the Grand Duchy of Finland. These collections (mostly in Swedish and Russian) are searchable online in the Astia service.

The Archives of the Finnish State Police Valpo holds numerous collections that are important sources for the research of Jewish refugees in Finland during the late I930s and the Second World War, the Finnish-German security police collaboration, and deportation of some Jewish refugees in I94I-2 to Nazi concentration camps and the treatment of the remaining refugees in Finland. The Military Archives (Sota-arkisto, also searchable online

Soviet Jewish prisoners of war in Finland. It also contains documents created by the Finnish State Police (Valtiollinen poliisi, Valpo), the Finnish Ministry of Justice and Finnish Finnish prime minister T.M. Kivimäki, all related to Jewish refugee issues and aid. The collection contains eighteen microfilm reels. The USHMM got these copies within the framework of the International Archives Project Division in April 2005. The original documents are stored in the National Archives of Finland. 
through the Astia service), on the other hand, hold collections that pertain to the history of Jewish soldiers in the Finnish army, Jewish women in the paramilitary organisation Lotta Svärd, to the Soviet Jewish prisoners of war in Finnish camps and the extradition of some of them to the German Security Police, and Finnish SS volunteers stationed on the Eastern Front.

\section{Jewish sources in the National Library of Finland}

Fennica - the Finnish National Bibliography - is a database at the National Library of Finland dedicated to Finnish imprints; it aims to hold a copy of everything published in Finland (Fennica 202I). Fennica thus has a vast collection of material printed by the Jewish communities. Significant are their journals, ranging from the first journal Suomen Juutalainen - Den Finske Juden (The Finnish Jew), published in Vyborg in I 908, to Hakebila (The Community) of the Jewish Community of Helsinki, which still runs. These journals provide valuable information about the social and cultural history of the communities.

The Hebraica Collection (Hebraica 202 I) of the National Library contains works in Hebrew and Yiddish published in the Russian empire (1828-r917), which the library received as deposit copies; it has been only partially catalogued. The collection's 5,000 items include, among others, various pieces of religious literature, textbooks, dictionaries, almanacs and calendars, and newspapers and periodicals.

The digital collections of the National Library hold digitised newspapers, journals and ephemera up to 3 I December I939, open to the public online (National Library $202 \mathrm{I}$ ). The over $2 \mathrm{I}$ million pages of digitised material with useful search tools have become an irreplaceable source for researchers and genealogists alike looking for material about Jewish history in Finland. The collections also hold many historical journals, especially those of the far right, important for studying antisemitism in Finland.

\section{Digitisation and infrastructures}

Several projects have aimed to digitise and make the collections more accessible over the last decade. The purpose of digitisation projects is always twofold: both preservation and increasing access.

Whereas the historical documents of the Jewish Community of Helsinki have been transferred to the National Archives, the life records - birth, marriage and death certificates - written after I 948 and the community's more recent archival materials, including. membership lists and certificates of conversions, have stayed onsite (altogether I7 linear metres). During 201 8-1 9, with the support of two grants, ${ }^{5}$ the onsite archive was reorganised and the oldest documents digitised (I.5 metres), and a search mechanism was created to help the staff locate the material. The records are organised systematically according to information. The language of the documents is primarily Swedish and Finnish; the indexing and the search mechanism are carried out in Finnish, Swedish and English. All these documents are of significant importance for current and former members and their relatives, and the administration of the community. Nevertheless, people can only be

5 The first extensive project was funded by the Rothschild Foundation Hanadiv Europe; project leader: Simo Muir, project workers: Dóra Pataricza and Mercédesz Czimbalmos. The digitisation of the oldest documents was done with the help of a grant from the Wihuri Foundation (Czimbalmos and Pataricza 201 9: 27-30). 


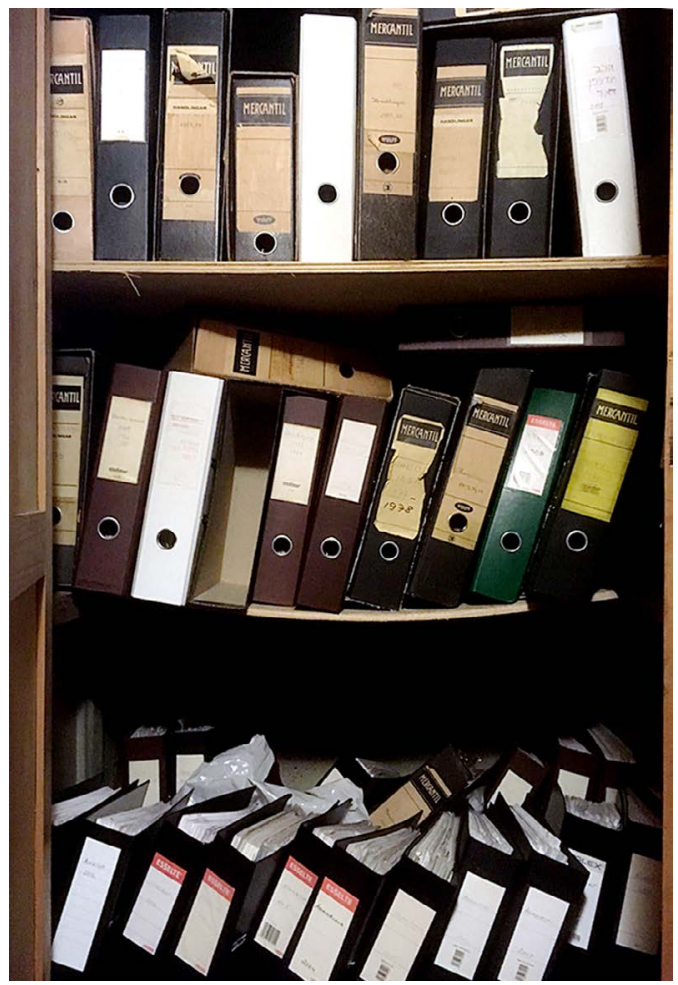

Fig. 2. The onsite archives of the Jewish Community of Helsinki before the cataloguing (September 2017). Photo: Beto Guzman.

granted access by special permission, owing to its strictly personal nature.

Besides records in the archives of the Jewish communities, another essential source for the history of Finnish Jewry is the opensource online platform of Meliza Amity (a renowned genealogist with Finnish Jewish roots), which serves as a genealogical databank, complemented by related sources, such as reports, photographs and censuses from as far back as I870 (Amity 202 I).

The archives of the Jewish communities and other archives with documents on the history of Jews in Finland have become part of international archival infrastructure projects. The National Archives of Finland became a partner of the European Holocaust Research Infrastructure (EHRI) when it was established in 20I0. The EHRI portal contains archival descriptions of holdings in Finnish archives about the Holocaust (EHRI 202 I). These descriptions include the archive of the State Police Valpo and the archive of the Finnish Red Cross POW Office (Suomen Punainen Risti, Sotavankitoimisto, searchable through Astia), both held at the National Archives, and records from the Archives of the Ministry for Foreign Affairs (Ulkoministeriön arkisto), dealing with Jewish refugees and the post-war trial of the Chief of the State Police, Arno Anthoni.

Most recently, in 2020, the National Archives joined the Yerusha project, funded by the Rothschild Foundation Hanadiv Europe (Yerusha 202I). The project aims to produce online archival descriptions concerning significant Jewish collections and other related documentation in Finland. At the heart of the project are the Finnish Jewish archives deposited at the National Archives of Finland. Besides this, the project will involve other central collections held at the National Archives and its regional divisions in Turku and Mikkeli and the archives of the Ministry for Foreign Affairs. The aim is to provide international scholars with research tools and essential information about archival holdings concerning the Jewish communities. Besides this, the archival descriptions will include documentation on the Jewish refugees in Finland before and during the Second World War and the Holocaust.

Over the past twenty years, several sets of interviews have been conducted, which have resulted in digitally preserved collections of oral history. In the early 20oos, Simo Muir did interviews in Yiddish that have been digitised and archived in the collection of the Institute of Languages in Finland (Kotimaisten kielten keskus, Kotus 202 I). In this project, he captured the cultural, historical and linguistic traits of the Jewish minority in Finland and how the cultural, political and religious ties 
to Eastern European Jewry have formed the communities in Finland. In 2019-20 in-depth interviews were conducted with various members of the Finnish Jewish community both in Helsinki and Turku within the project 'Boundaries of Jewish Identities in Contemporary Finland - "Minhag Finland"' (Project leader: Associate Professor Ruth Illman, Åbo Akademi University) (Minhag Finland 202 I). Nordisk judaistik/ Scandinavian Jerwish Studies 30(I) in 2019 was entirely dedicated to different aspects of contemporary Jewish life in Finland. The interviews were aimed at capturing how members of Finnish Jewish communities live their everyday lives, what kind of traditions they have and how they perceive themselves. The main themes of the interviews are food, marriage and family, and religious and cultural traditions. The material was collected according to the Personal Data Act (Henkilötietolaki) and is kept anonymously in the archives of the Finnish Literature Society (Suomalaisen Kirjallisuuden Seura).

\section{Norway}

Jews were allowed into Norway only in I $85 \mathrm{I}$, owing to a ban in the Constitution of I 8 I 4 . Until the immigration of Eastern European Jews from the I880s onwards, the Jewish population was minimal and hence the archival material is of relatively recent date. However, that also means that there are many archival sources for those wanting to study the history of Norwegian Jews.

The most important archives regarding the Jewish communities in Norway are in the Jewish museums of Oslo and Trondheim. These are mainly, but not solely, the archives of the two congregations, but they also shed light on the Jewish community at large in Norway. There are also important documents in various departmental archives at the National
Archives of Norway (Riksarkivet). Most documents in any archive are in Norwegian, although a few are in Yiddish, Hebrew and German. Interestingly, there are hardly any in Russian, even though most Jewish families in Norway before the Second World War originated in shtetls in tsarist Russia.

\section{The Jewish museums: secular and religious Jewish life in Norway}

Jews in Norway mainly settled in Oslo and Trondheim, the only two places where they formed organised religious communities. The Jewish Community of Oslo (Det Mosaiske Trossamfund, DMT), has always been the larger, and the one the highest degree of interaction with the authorities, although the Trondheim community dealt with local matters when needed. While the archives in Trondheim are incomplete up to the outbreak of the Second World War, the archives of the Oslo community (DMT) contain objects, correspondence, membership records and minutes from meetings in the congregation and related organisations (e.g. the burial society Chevra Kadisha) since its founding in I 892 and up until 1975 .

The Oslo Jewish Museum (Jødisk Museum i Oslo) also holds the archival material of a Jewish congregation called 'DIM' (Den Israelitiske Menighed), which was founded in I9I7 and merged with DMT after the Second World War. Congregational archival materials after 1975 are situated in the synagogue complex of the DMT. While the archive certainly deals with religious issues, it also provides glimpses into everyday Jewish life in the period. In addition, the Oslo Jewish Museum also holds records of other organisations, such as the Jewish youth organisation and women's organisations. Unfortunately, these collections are incomplete. There are also a few private archives, photos and other 
material (e.g. diaries, diplomas, letters and artefacts) donated to the museum by individuals (Oslo Jewish Museum).

The post-war archives of the Jewish Community in Trondheim (Det jødiske samfunn i Trondheim, until 20I 7 Det Mosaiske Trossamfund) are situated in the Jewish Museum Trondheim (Jødisk museum Trondheim). The museum holds a compilation of minutes from meetings in the congregation until r 969 and correspondence to and from the congregation up to 2000 . It also has an incomplete collection of objects, and material from different local Jewish organisations and individuals. In addition, it holds a collection of 8,500 photos related to the community throughout its history (Komissar and Banik $202 \mathrm{I}$ ).

\section{Other archives}

The Norwegian Museum of Cultural History (Norsk Folkemuseum) holds 'Wergelands barn' (Wergeland's children), a collection of oral interviews conducted with thirty-eight elderly Norwegian Jews around 2000. The interviews cover the stories of their lives, their families, the history of their ancestors in Eastern Europe and their migration to Norway, their upbringing, and the Second World War and its aftermath. The collection also contains photos and interviews related to the pictures. The interviews and photos are a unique source for a Norwegian Jewish past that, in many ways, has existed under the shadow of the religious organisation of the two congregations and the Holocaust. There are restrictions on use, and researchers and others must apply for access through the museum.

The National Library of Norway (Nasjonalbiblioteket) holds microfilmed copies of the Norwegian Jewish periodicals Hatikwoh, Israeliten, Jødisk Tidende and Jødisk Nytt. This is another way of securing important information about Jewish life in Norway in the interwar period and the period right after the Second World War. These periodicals contain minutes from meetings of different organisations and hence constitute an essential addition to the incomplete archives of the two Jewish museums. In addition, the periodicals give examples of topics of interest to the Jewish population at the time, be it Zionism and the establishment of Israel, Jewish Nobel laureates or local antisemitism.

Two other interesting non-Jewish sources of Jewish life are the national and communal censuses. The latter are in different local or regional public archives (Oslo City Archives, Oslo byarkiv). While the communal censuses are conducted more frequently, the national censuses take place every decade. As for the latter, digitised versions are published after a century has passed. However, newer public censuses are accessible for researchers and others in their original form in the National Archives (Public censuses, Folketellinger). Both communal and national censuses give detailed information on where Jewish individuals live, their occupation, place of birth, etc. Hence, by tracing the place of habitation and occupation, it is possible to proffer substantial observations, for example, on social mobility over a longer period. An additional source with similar potential is address books (Adressebøker), annual printed directories somewhat like phonebooks. These are accessible online (National Library of Norway, Digital Archives). An important limitation is that the names of the Jewish individuals concerned need to be known in order to conduct a search. In Norway, where the Jewish population never exceeded 2,000 individuals, this is not a significant problem. Hence, Jewish genealogy is relatively easy in Norway. 
al. 2020; Søbye 202 I). Hence, Norwegian antisemitism among non-Nazis before and during the war is one factor that may help us understand why and how the Holocaust could happen in Norway; it is hence relevant in the context of this article. However, here we will only mention one archive.

Material that sheds light on institutional antisemitism is in the archives of the Department of Justice at the National Archives. The handwritten notes of national and local bureaucrats often reveal antisemitic prejudices and are an interesting source for mapping anti-Jewish sentiments in the interwar period in Norway. This archive is also interesting because it provides information on the reasons for emigration from Eastern Europe, on the Jews' journeys to Norwasy, and on the dates of their arrival in Norway. Often, we can also get information on their socio-economic status, as one crucial criterion for citizenship was the perceived possibility of providing for themselves and their family in the future.

\section{Ongoing archival projects}

While the two Jewish museums, Oslo Jewish Museum and the Jewish Museum of Trondheim, through their curators, encourage individuals and organisations to donate objects and archival material, their capacity in terms of storage and labour is limited, and hence their approach to acquiring documents is also limited. The Norwegian Center for Holocaust and Minority Studies has the same challenges, and its collection is further limited to material more closely connected to the Holocaust. For the time being, there are no ongoing projects in other archives regarding the Jewish population of Norway past or present.

\section{Sweden}

There are several records of Jews who lived in Sweden temporarily before the arrival of Aaron Isaac, the first Jew to be allowed, in $\mathrm{I} 774$, to settle in the country with his family without giving up his religion. In the sixteenth and seventeenth centuries, a small number of Jews resided in Sweden in their capacities as royal physicians, purveyors and language tutors. In the late seventeenth century, several Jewish families were baptised, which was a requirement for permission to settle in Sweden. Aaron Isaac was soon followed by other Jewish families, who settled and practised certain professions and trades after obtaining the necessary permits. In 1782 a decree, the so-called Jewish Ordinance (Judereglementet), was issued, treating the Jews as a separate corporation, the Jewish nation, and permitting them to reside in Stockholm, Gothenburg and Norrköping, under certain conditions. ${ }^{6}$ When the ordinance was repealed in 1838 , Jews were no longer considered a separate nation but Swedish citizens of the Mosaic persuasion (Carlsson 202 ra; Valentin r924a).

Sources of Jewish history in Sweden can be found in many collections in different archives. For obvious reasons, we cannot mention all archival collections that include sources of Jewish history in Sweden, but we will try to provide a brief overview of some of the most important collections in the country. However, a comprehensive guide to the sources to Jewish history in Swedish archives (Carlsson 2022) is under publication by the

6 Through a separate concession a small Jewish community in Karlskrona was permitted and between I 775 and 1794 there was also a small Jewish congregation in Marstrand that had an exceptional status as 'Porto Franco' (free port). 
Sponting YY... 21 Octol 1659

《)?

$$
\begin{aligned}
& \text { Otwrecstigite fon's, } \\
& \text { ularnáliges bren, }
\end{aligned}
$$

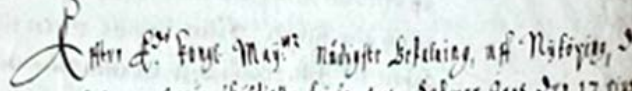

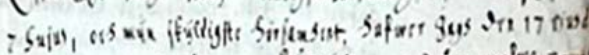

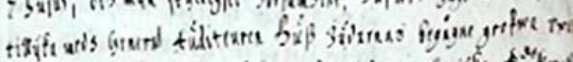

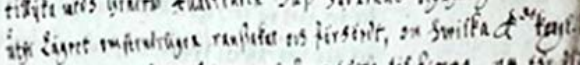

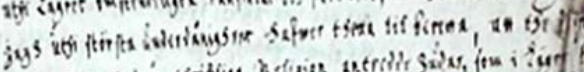

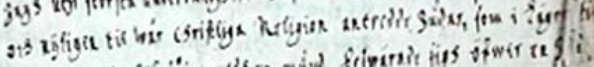

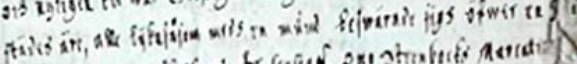

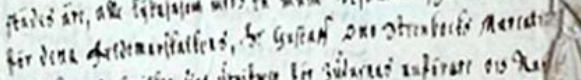

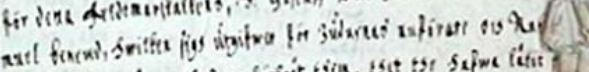

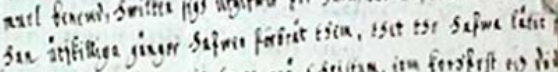

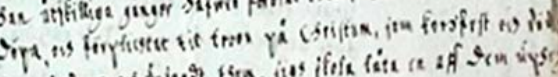

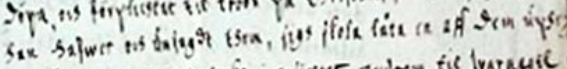

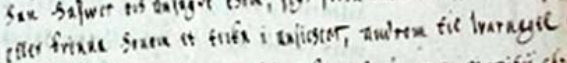

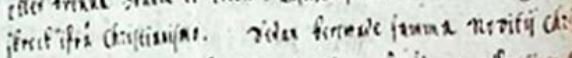

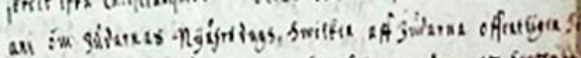

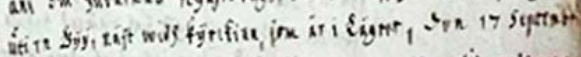

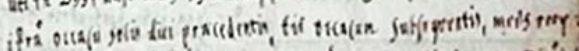

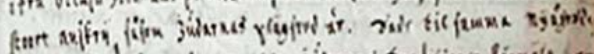

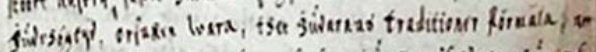

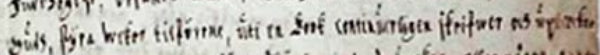

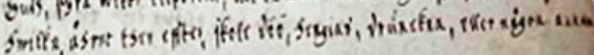

\section{त)}

Fig. 4. The oldest document in the National Archives of Sweden collection in the Acta Ecclesiastica series about Jews is a letter to the king from a priest and general superintendent in the army, Zacharias Klingius, from October 1659. In the letter, he testifies to an incident in connection with the Swedish siege of Copenhagen. A group of Jews had been arrested in a nearby tent camp for holding a sermon on Rosh Hashanah without permission. According to the letter, the Jews were also accused of having punished Jews who had converted to Christianity physically and by burning effigies of them. Photo: Pontus Rudberg.

National Archives and a selection of Jewish archival collections has been indexed and described in the Swedish part of the Yerusha Sweden project. $^{7}$

7 This project was funded by the Rothschild Foundation Hanadiv Europe.
The archives of the Jewish communities of Sweden, especially the communities of Stockholm, Gothenburg and Malmö, contain rich sources of Jewish history from the time of the first permitted Jewish immigration to the country up to the present. These include demographic records, statutes, protocols, correspondence, audit reports and more detailed administrative records of the building and management of synagogues and burial grounds, the religious education of Jewish children, poor relief and the burial society of each town. They also hold private collections of some of their more renowned congregants and special collections of cultural and historical value such as note sheets and other musical collections, photo collections, newspaper clippings, architectural drawings of synagogues and other community buildings. Some of the correspondence in these archives is not only of national interest but also constitutes essential sources to the Jewish history of other countries, as the Swedish Jewish communities were in contact with Jewish communities abroad. Since Sweden was not invaded in the Second World War, Jews in Sweden could organise and carry out refugee aid and relief for Jews in Europe. Sweden became one of few transit countries for refugees. Many international Jewish organisations had branches or representatives in Stockholm, and Swedish Jewish organisations frequently corresponded with foreign Jewish communities, organisations and individuals.

The archive of the Jewish Community of Stockholm (Judiska församlingen i Stockholm) is the largest of the community archives. The $3 \mathrm{I}_{5}$ linear metre archive is organised into 85 sections. It holds records of previous and present members, administrative and financial records, correspondence, certificates, memos and reports, pictures and photos, diaries, manuscripts and other 
documents from the I770 up to today. ${ }^{8}$ The archive also includes the archives of several other organisations and private archives of rabbis and other individuals. It also contains large amounts of correspondence with foreign Jewish organisations and individuals whose own archives, in many cases, have been destroyed. The archive is currently accessible in its facility in the National Archives facility in Täby in northern Stockholm. ${ }^{9}$

The second-largest Jewish community in the country, the Jewish Community of Gothenburg (Judiska församlingen i Göteborg), is said to have been founded in 1780 , and over the following decades, the small community grew to around 4I5. From the I 83 os, the community was known to be very liberal, and many of its members contributed significantly to the city's flourishing industry and cultural and political life. Of the Jewish families who immigrated to Gothenburg before the r 870 os only a few remained as members of the Jewish community. Most current members are descendants of immigrants from tsarist Russia, Holocaust refugees and survivors, and refugees from countries in Eastern Europe, not least Poland. The majority of the community's archive, around 44.3 linear metres, is deposited with the Regional Archives in Gothenburg (Regionarkivet i Göteborg), while some, mostly more recent, documents are still located at the community's

8 Some of the older demographic records in the archive of the Jewish Community of Stockholm have been digitised and made available online, through the digital portal ArkivDigital.

9 The index can be found online in the archive's database Nationell Arkivdatabas (NAD). NAD also includes both state and some of the regional and municipality archives, including Jewish community archives, although not the Jewish Community of Gothenburg. premises. In addition to the administrative archive of the community, it also includes the archives of various Jewish organisations associated with the community.

The archives of the smaller Jewish communities in Sweden are spread across regional and municipal archives. Founded in $187 \mathrm{I}$, Malmö is today the third-largest community after Stockholm and Gothenburg, while the recently dissolved Norrköping community was one of the first cities that Jews were permitted to settle in in the late eighteenth century. ${ }^{10}$ Between the I870s and the early twentieth century, several new Jewish communities were founded in Sweden. In addition to the community in Malmö, there are archives from the communities in Kalmar, Oskarshamn and Växjö in regional archives. ${ }^{11}$ Also, in the National Archives is the archive of one of the oldest Jewish communities in Sweden, the small community of Karlskrona (I 785-I 994).

Some Jewish organisations' archives form sub-archives within the archives of the Jewish communities, while others have separate archives (see Carlsson 2022 for an overview).

\section{State archives}

Several different state archives hold collections that contain important sources for Jewish history. In some cases, these collections date back to the time before the first wave of permanent Jewish immigration. For instance, the collection of ecclesiastical documents in the National Archives of Sweden, Acta

10 Both archives are deposited with the city archives in the respective cities.

11 Membership in a religious congregation was compulsory in Sweden until I95 I. Since 1952 membership has been voluntary and a majority of the country's Jews today are not members in any Jewish community. 
Ecclesiastica, includes around a thousand sheets in folders. One folder, called 'Petitions from Jews and converted Jews' (Suppliker av judar och omvända judar) contains letters and petitions to the Swedish state (Kungl. Maj:t) with requests for Jews to be permitted to stay in the country, to obtain so-called 'protective passports' (skyddspass) and the right to carry out trade, industry or certain professions, and with time also for citizenship.

As mentioned, the Jewish minority in Sweden was initially treated as a separate corporation, regulated by the 'Jewish regulations' and the National Board of Trade (Kommerskollegium) was assigned to its control. According to the Jewish Ordinance, the four permitted Jewish communities (Stockholm, Gothenburg, Norrköping and Karlskrona) annually submitted reports about their congregants to the Board of Trade. In addition to these there are also reports on the Jewish population in Vasa in Finland, until I 809 when Sweden lost Finland to Russia. These reports and other documents, including some correspondence between the board and the community leaders, are preserved in the archive of the board in a collection called 'Judar i städerna' (Jews in the towns). The archive is currently being indexed and the new index will be added to Nationell Arkivdatabas (NAD).

The files of the Swedish immigration authorities, such as the National Board of Health and Welfare (Socialstyrelsen), the Ministry for Foreign Affairs (Utrikesdepartementet), the State Police Bureau (Statens polisbyrå) and the State Foreigners Commission (Statens utlänningskommission, SUK), are also excellent sources for research on individuals as they contain documentation on the contacts between foreigners and the government, including police interviews and personal documents. In the case of Holocaust survivors, other state and regional archives hold collections of personal files from hospitals and refugee centres, and interviews and reports by the border police. There are useful archival guides but, unfortunately, only in Swedish (Carlsson 2022; Rudberg 2020; Hallberg 200I).

The National Archives of Sweden also hold several smaller archives of companies, families and individuals that include important sources for Jewish history. The personal and business archive of the businessman and Jewish community leader Fritz Hollander, for example, contains documents about the Jewish Community of Stockholm, other Jewish organisations, including the Swedish Section of WJC, and family and personal documents. ${ }^{12}$ The National Archives also hold the personal and family archive of Fritz Hollander's father-in-law, Jacob Ettlinger, who was also the chairman of the orthodox synagogue association in Stockholm, Adat Jisrael.

\section{Other archives}

Several museums also have collections and archives that hold sources for Jewish history. The Jewish Museum in Stockholm (Judiska Museet) has numerous smaller personal archives, including the archives of the photographer Anna Riwkin-Brick and the psychiatrist Esther Lamm. ${ }^{13}$ The

12 The archive is deposited with the National Archives in Marieberg and has recently been indexed. It is accessible for researchers but a permission from the depositing owners of the collection is required. The index is available online through NAD.

13 The museum has recently received a grant from the Rothschild Foundation Hanadiv Europe in order to organise and index its archive and continues to register its collections in the Swedish museum collections database, DigitaltMuseum. 
Nordic Museum (Nordiska museet) also has a collection based on a project 'Judiska minnen' (Jewish memories) carried out by the museum between r994 and I998. The collection includes so-called life stories of Swedish Jews and transcripts of interviews made with Swedish Jews, Holocaust survivors and social workers and other individuals who came into contact with the survivors. There are also interviews on audio and video tapes and photographs and documents, diaries and correspondence (Johansson 2000; Thor Tureby 201 9; Thor Tureby and Wagrell 2020a). ${ }^{14}$

In addition to the personal archives of Jews, mentioned above, there are several other Jewish personal archives in Sweden. For example, the Stockholm City Archive (Stockholms stadsarkiv) holds the collection of the former Consul General Olof Lamm, a Swedish Jewish diplomat and businessman. It contains his personal correspondence with family, friends and acquaintances about private matters and business, and issues regarding Jewish organisations. Parts of the collection contain correspondence about the persecution of the Jews in Nazi Germany, discussing the responses of various states and exchanging information on possible safe havens for refugees. ${ }^{15}$

The University of Gothenburg has the private collections of some of the city's most prominent Jewish families and the National

14 The collection is available for researchers on certain conditions only. The index is anonymised and permission to see the archive is issued by the head archivist of the museum, who must be contacted in advance.

15 The archive, organised by the Stockholm City Archive, and the index can be accessed through NAD. Most of the material is open to the public but for some parts a permission in advance by the Stockholm City Archive is needed.
Library of Sweden (Kungliga biblioteket) holds a number of personal archives of Swedish and foreign Jewish personalities. The collections include the archive of the literature professor Martin Lamm and the economic history scholar Eli F. Heckscher. The library also holds the archive of the German Jewish poet in exile, Nelly Sachs, and many more Jewish cultural personalities, and nonJewish individuals whose correspondence includes letters to and from Jews. Carlsson's archival guide includes a list of all known Jewish personal archives in Sweden (Carlsson 2022).

\section{Sources for the history of the Holocaust and antisemitism in Sweden}

There are numerous sources about the history of the Nazi persecution of the Jews and the Holocaust in Swedish archives, libraries and museums. However, no single institution has undertaken to collect such documentation to build a comprehensive collection. Therefore, documents and other types of sources are spread across Swedish official archives and the archives of organisations and private collections (Rudberg 2020: 193-275).

The archives of the Jewish communities hold documents that reveal what information Swedish Jews had about the different stages of the Nazi persecution and the Holocaust and how they responded to this information. Many organisations (Jewish and non-Jewish) came into contact with the events in Europe and/or with refugees and survivors, not least through relief activities (Rudberg 20I7; Maier-Wolthausen 2019; Rudberg 2000: I93-275).

Several Swedish state archives include documents that reveal what information was at hand about the different stages of the Holocaust and about Swedish responses to this information. For instance, the 
archive of the Ministry for Foreign Affairs (Utrikesdepartementet, UD) includes reports and correspondence about the situation of Jews in Nazi controlled Europe as well as about potential Jewish immigration. Some of these documents have been compiled into a separate collection, which is also available on microfilm in the National Archives. Other UD-collections deal with the Swedish Red Cross (Röda Korset) rescue mission to Germany in I945 and the UNRRAoperation through which survivors from German concentration camps were brought to Sweden in the summer of the same year. Numerous other archives include documentation of Holocaust refugees and survivors in Sweden. 16

In addition, there are several collections of testimonies and other statements made by refugees and survivors about their own experiences, for example, in different forms of applications, surveys and protocols from interviews. There are collections of transcripts and protocols of interviews with survivors from I 945 in Swedish archives, and there are also several later collections of interviews (Heuman and Rudberg 202I; Thor Tureby and Wagrell 2020a). For instance, in its archive, Lund University Library holds the Polish Research Institute archive, which contains interviews with women survivors of Ravensbrück and ten other concentration camps (van Orden Martinez 202I; Dahl 202 I). 17

In January $202 \mathrm{I}$, the Swedish government declared that a museum about the Holocaust

16 As mentioned above there are also several personal archives in the National Archives that include sources about the Holocaust.

17 The material is partly digitised and translated into English. The digitised material and a detailed index of the collections can be accessed from the library's homepage. would be opened in 2022. The Forum for Living History (Forum för levande historia, FLH) was assigned to collect 'memories' in the form of testimonies, objects, letters, diaries, photographs and other material connected to the Holocaust and Sweden. The collected material will later be transferred to the new museum.

Also, the Swedish history of antisemitism predates the first Jewish permanent immigration. From the late eighteenth century on, however, sources include press material, parliamentary debates, institutional material, press material, literature, pamphlets and other ephemera, different types of judicial material from police sources and claims filed in civil court cases to court verdicts, sources from state archives, diaries and private correspondence (see Heß 202I; Kvist Geverts 2008; Lööw 20I5, I998; Carlsson 2004; Nyman I988; Tydén I988; Johannesson I988; Andersson 2000; Blomqvist 2000; Rosengren 2013; Bachner 2009, I999).

\section{Recent and ongoing archival projects}

So far, the most significant challenge for researchers in Swedish Jewish history has been to locate the many Jewish sources that are spread across Swedish archives, libraries and museums. There are generally indexes, but they often do not reveal if the archival collection in question contains sources related to Jews. However, Carl Henrik Carlsson has recently written a comprehensive yet detailed archival guide to sources of Jewish history in Sweden that is currently awaiting publication (Carlsson 2022). The guide will be a valuable resource for all Swedish-speaking researchers and students. However, a very useful complement to Carlsson's guide is the National Archives' guide to sources for immigration history (Hallberg 200I). Also, the Forum for Living History has recently published a 
survey of Holocaust testimonies in Swedish archives (Thor Tureby and Wagrell 2020).

Recently, the 'Yerusha Sweden' project has explored, indexed and provided a more detailed description of around one hundred individual 'Jewish collections' in different Swedish archives. ${ }^{18}$ Furthermore, the United States Holocaust Memorial Museum (USHMM) has funded the scanning of many of the Holocaust-related documents from the Jewish Community of Stockholm, which will be available through the USHMM archives.

\section{Challenges: search mechanisms, access, new acquisitions and digitisation}

There are several common challenges concerning Jewish collections in the Nordic countries. One of the biggest challenges has to do with lack of online information about the collections and appropriate digital search mechanisms. For instance, in Sweden, with probably the highest number of Jewishrelated collections in the Nordic countries, there is a lack of useful metadata, and what exists is often only in Swedish. This results in the fact that although many sources would possibly be of great interest to international researchers, they remain buried in the collections. This seems to be a problem also for local researchers because the material is vast and spread across state, regional, institutional and private archives. This can possibly explain the tendency for studies of Jewish communities, organisations and individuals to be based on sources from the archives of an isolated community or organisation, or even an individual.

18 In addition to these the Jewish Museum in Stockholm has received another grant from Rothschild Foundation Hanadiv Europe to explore and organise its own archive and to add the details to the Yerusha database. The museum is also digitising and publishing parts of its collections online.
There is an obvious risk that individual documents are given disproportionate importance when studies based on limited archives or even individual statements are said to be representative of larger Jewish groups.

In Finland too there is a need for online catalogues and search mechanisms. The gap between the old archival system with paper catalogues and the new possibilities offered by digital solutions should be bridged so that the material on Finnish Jewry can be accessible also from abroad. Also, the rules on who has access, and how, to the Finnish Jewish Archives are often unknown to researchers, even the members of the Jewish communities or descendants abroad. These rules ought to be more explicit, more accessible and more transparent.

\section{Access and data protection}

Owing to the sensitive character of the documents stored in the Jewish archives, researchers face several challenges in all Nordic countries. In Sweden, the archive of the Jewish Community of Stockholm, which is deposited with the National Archives, is available for academic and genealogical research. However, a permit from the Jewish community of Stockholm is required and the request should be made to the National Archives. The National Archives then gives their recommendation, which is generally followed by the Jewish community. Lately, the National Archives have recommended that the Jewish community should not give history students on BA-level courses access to the archives. This, of course, hinders students from becoming familiar with the sources, which in turn impairs the growth of scholars in Jewish studies.

Similarly, the archives of the Jewish communities of Gothenburg, Malmö and Norrköping are deposited with the regional 
and municipality archives. Although formal permission is requested to access these archives as well, this is generally granted swiftly. Also, the 'Judiska minnen' (Jewish memories) collection in the archives of the Nordic Museum has been reported as difficult to access. Recently, Malin Thor Tureby and Kristin Wagrell (Thor Tureby and Wagrell $202 \mathrm{Ob}$ ) argued that the museum, by restricting access to academic research regarding the alleged vulnerability of Jews, has contributed to the construction of Jews as indeed vulnerable. However, there is no evidence that the museum has restricted access with any other motive than to protect the respondents' integrity and safety and to follow Swedish and European legal provisions about the protection of personal details. However, if students or scholars in Jewish studies do not get access to the sources, this is a problem that needs a solution.

In Denmark, the Archives Act of $2 \mathrm{I}$ August 2007 specifies that sensitive personal information on individuals - regardless of their status as perpetrators or victims - in classified archival materials from the Danish National Archives should be anonymised. Similarly, as with other Nordic countries, religious and political affiliation is by law considered personal information. It represents a challenge when working with archives of minorities since the mere presence of individuals (and their names) in the archives indicates their minority status. Furthermore, the vital process of identifying, collecting and systematising personal information of individuals belonging to a minority must abide by the General Data Protection Regulation regulations, specifying regulation for gathering and storing systematised information. As to the anonymisation of Holocaust victims, the position of the Danish National Archives has been criticised as counteracting the dedication to identify and honour individual victims.
The sheer number of Jews in Norway and their (perceived) vulnerability as a minority with a difficult past is also a cause of challenges. Individuals in the archives are often someone's relative or ancestor, and researchers might even get phone calls from descendants asking why they wrote about their ancestors.

Although anonymity in all cases may help if the research topic is sensitive, individuals may still be easily recognised. These issues might also affect potential donors from donating private material to museums or archives and what museums eventually decide to keep. Lastly, this might be a reason why congregations decide to keep a lot of the relatively recent material, which then again creates the question of how they decide what to keep or not.

\section{Acquisition of new collections}

In the case of Finland, it is only recently that the archives of the Finnish minorities have come under the radar of the Finnish archival institutions, and minority collections, especially of private persons and families, have thus been neglected in various acquisition goals and overall strategies. For instance, for decades, the National Archives of Finland have collected material about the Second World War from private persons, yet now they are turning down such material offered to them. However, such material from Jewish families is scarce, and the material may not be accepted because the archives have gone beyond this historical phase. To avoid this, archivists should always be more sensitive about collections from minorities and consider them from the minority's perspective, not the majority's.

Despite the initiative in 2010 at the National Archives of Finland to acquire Jewish private archives, there is still a massive gap in this material available for researchers. 
There are perhaps several reasons for people not being willing to part with their family collections, such as the emotional attachment and the lack of understanding of the importance of the material from a broader historical and cultural point of view. These reasons often lead to getting rid of the materials. Thus, a more active acquisition plan and easily accessible knowledge on how private individuals can donate material are needed. If depositing materials is not an option, digitising can provide an alternative way to secure the preservation of the documents for posterity.

In Norway, one of the challenges lies in the prominence of the Holocaust. Even though Norwegian Jews are regarded as one of five national minorities, public archives do not seem to take any systematic interest in Jewish life before and after the genocide. Hence, with their limited resources, the two Jewish museums, as with the Danish instance, are left with the difficult task of deciding what is to be preserved or not.

There are several collections of documents and other sources about the Holocaust in Sweden, owned by survivors and their relatives. However, it is challenging for the researcher to get an overview of private sources that are not accessible through an archival institution since there are no systematic surveys of these collections. In some cases, this seems to be a consequence of the owners' experience of finding nowhere to turn to to have their collections taken care of without risking the documents being sifted out and destroyed later on. Survivor organisations and individuals have repeatedly requested an institution to deposit documents and artefacts. The Jewish Museum in Stockholm is small and has limited resources and can only accept some of the many gifts and deposits it is offered. It remains to be seen if the new Swedish Holocaust Museum will be able to fill this need.

\section{More digitising needed}

The digitisation of Jewish collections in the Nordic countries is proceeding slowly and, in most cases, the digitised documents are not available outside the walls of the archives. In the case of Norway, most of the archives mentioned in this article are, unless otherwise stated, only accessible physically. Some of the holdings of the two Jewish museums are digitised but not published online. As for national, regional, or local archives regarding Jewish life in Norway, access to the actual digitised documents is rare. However, the National Archives of Norway are ready to provide a limited number of scanned copies on demand, which is true also for Denmark.

Similarly, in Finland only fragments of the records in the Jewish collections have been digitised, let alone being accessible online. Several documents have historical and administrative value and are of crucial importance for the members and the administration of the communities and even for international researchers. In some cases, the poor and fragmentary condition of the records justifies the need for digitisation, as in the case of pinkasim from the nineteenth century. The vast Jewish photo collection in the National Archives of Finland has not been digitised even though the users have suggested this several times.

Recently, Covid-i9 has entirely transformed the world of researchers as well. The need for accessing a possibly wide range of digitised archival material from our desktops at home has never been as crucial as now. Currently, all materials in the Nordic archives are hard to locate and navigate, and even more difficult for non-Nordics. Scanning is both time-consuming and expensive. A joint database with detailed metadata in English and additionally a few keywords would be of use to researchers to get a view of where material of Jewish interest is located. 
Sofie Lene Bak, PhD, is associate professor in modern history at the Saxo Institute, University of Copenhagen, Denmark. She is the author of several books and articles on antisemitism,

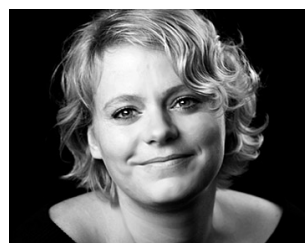
Danish Jewish history and the Holocaust, among them Dansk antisemitisme 1930-1945 (Danish antisemitism 1930-45) (Aschehougs Forlag 2004), Nothing to Speak of: Wartime Experiences of the Danish Jews 1943-1945 (The University of Chicago Press 2012) and Da krigen var forbi (When the war was over) (Gyldendal 2012) on the repatriation and restitution of the Danish Jews after the Holocaust.

\section{Vibeke Kieding Banik,}

Ph.D., specialises in

Norwegian Jewish history. She is currently head of education at the Norwegian Center for Holocaust and Minority Studies and a part of the research project 'Negotiating Jewish identity: Jewish life in 21 st-century Norway', funded by the Norwegian Research Council.

Bjarke Følner is a historian and social researcher. $\mathrm{He}$ is the chairman of the Society for Danish Jewish History and a former curator at the Danish Jewish Museum (2007-12). Currently, Bjarke works as a senior consultant at Als Research in Copenhagen.

\section{Simo Muir, Ph.D.,} is a Yiddish scholar specialised in Finnish Jewish cultural history. During 2005-10 he worked as an archivist in the National Archives of Finland, cataloguing the Finnish Jewish Archives. Currently, Muir is co-investigator in a project entitled
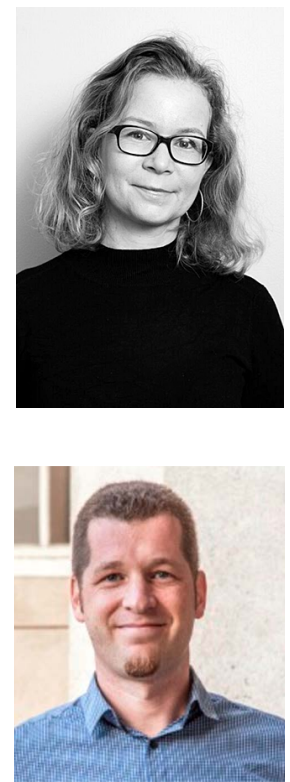

'Boundaries of Jewish Identities in Contemporary Finland' at the Åbo Akademi University in Turku, Finland.
Dóra Pataricza, Ph.D., is a post-doctoral researcher in history who worked at the Jewish Communities Szeged (Hungary) and Helsinki at projects aiming to index, catalogue and digitise the Jewish archives. Currently, she is working as a parttime post-doctoral researcher at Åbo Akademi University in Turku, Finland, in a project entitled 'Boundaries of Jewish Identities in Contemporary Finland'. Since January 2020, she has also been a project manager in the Jewish Community in Szeged, financed by the Claims Conference and International Holocaust Rememberence Alliance (IHRA), to reconstruct the fate of Hungarian and Bačka-Serb victims of the Holocaust.

\section{Pontus Rudberg,}

Ph.D., is a historian and researcher at the Hugo Valentin Centre, Uppsala University. From 2019 to 2021 he was the project leader of the Jewish Museum in Stockholm's part project of the international Jewish archival project 'Yerusha'. Rudberg is one of the co-editors of Early Holocaust Memory in Sweden (Palgrave Macmillan 2021) and the author of The Swedish Jews and the Holocaust (Routledge 2017) and as well as several articles and book chapters in Jewish history. He is currently researching the accommodation and rehabilitation of Holocaust survivors in Sweden.

\section{References}

\section{Archives and data collections}

\section{Denmark}

Danish-Jewish Funerals and Tombstones up to I $886,<$ http://tom.brondsted.dk/ mosaiskebegravelser/?lang=en $>$ (accessed 7.10.202I).

Danish-Jewish Genealogical Database, <http:// tom.brondsted.dk/djgdb/?ged = I \&lang=en > (accessed 7.10.202 I).

The Danish Jewish Museum. 'Museernes samlinger' (Objects in the collection), <https://www.kulturarv.dk/mussam// VisMuseum.action?museumId= I I I > (accessed 7.I0.202 I). 
The Danish Jewish Museum. 'Kunstindeks Danmark' (Works of art in the collection), <https://www.kulturarv.dk/kid/VisMuseum. do? museumId=I I $>$ (accessed 7.10.202 I).

The Danish Jewish Museum and Danish Institute for International Studies. 'Safe Haven'. Dansk Jødisk Museum, <https://safe-haven.dk/en/> (accessed 7.I0.202I).

Danish National Archives. 'Arkivalieronline', $<$ https://www.sa.dk/en/services/ arkivalieronline/archives-online/> (accessed 7.10.202I).

Danish National Archives. 'Det jødiske samfund i Danmark', <https://www.sa.dk/daisy/ arkivskabers_arkivserier?ngid $=$ I 5 I 5025 \&ngn $\mathrm{id}=2 \mathrm{I} 45 \mathrm{O}$ I $80>($ accessed 7.10.202 I $)$.

Danish National Archives. Search engine 'Daisy', $<$ https://www.sa.dk/daisy/daisy_forside> (accessed 2I.II.2O2I).

Museum of Danish Resistance. 'Museum of Danish Resistance: Photo Archives', National Museum of Denmark, <https://en.natmus. $\mathrm{dk} /$ museums-and-palaces/the-museum-ofdanish-resistance/archives/photo-archives/> (accessed 7.10.202I).

Royal Danish Library. 'The David Simonsen Archives', <http://www5.kb.dk/en/nb/ samling/js/DSintro.html> (accessed 7.10.202I).

Royal Danish Library. ‘The Judaica Collection', $<\mathrm{http} / /$ www5.kb.dk/en/nb/samling/js/index. html> (accessed 7.10.202 I).

\section{Finland}

Amity, Meliza. 202 I. 'Meliza’s Genealogy', $<$ https://www.amitys.com> (accessed I $5.9 .202 \mathrm{I}$ ).

Astia. 202 r. 'Astia verkkopalvelu', National Archives of Finland, <https://astia.narc.fi/ astiaUi/?lang $=$ sv $/>($ accessed I 5.9.202 I $)$.

Digitaaliarkisto. 202 I. 'Helsingin juutalaisen seurakunnan arkisto -arkiston sarjat', National Archives of Finland, <http://digi.narc.fi/digi/ dosearch $\cdot$ ka?atun $=3266 \mathrm{I} \mathrm{r} \cdot \mathrm{KA}>$ (accessed I 5.9.202 I).

EHRI. 202 r. 'Finland', European Holocaust Research Infrastructure, <https://portal.ehriproject.eu/countries/fi> (accessed I 5.9.202 I).

Fennica. 202 I. 'Fennica: the Finnish National Bibliography', National Library of Finland, $<$ https://www.kansalliskirjasto.fi/en/ node/I 748> (accessed I 5.9.202 I).

Hebraica. 202 I. Hebraica: the Finnish National
Bibliography', National Library of Finland, $<$ https://fennougrica.kansalliskirjasto.fi/ handle/I $0024 / 85838>$ (accessed I 5.9.202 I).

Kotus. 202 I. 'Kotuksen arkistot', Institute for Languages of Finland, <https://www.kotus.fi/ en/services/archives> (accessed I 5.9.202 I).

Minhag Finland. 202 r. 'Boundaries of Jewish Identities in Contemporary Finland "Minhag Finland"', Polin Institute, <https:// polininstitutet.fi/en/boundaries-of-jewishidentities-in-contemporary-finland-minhagfinland/> (accessed I 5.9.202 I).

National Library, Finland 202 r. 'Kansalliskirjasto avasi I 930-luvun digitoidut lehdet asiakaskäyttöön', Kansalliskirjasto I 5.I.2O2 I, $<$ https://www.kansalliskirjasto.fi/fi/ uutiset/kansalliskirjasto-avasi-I 930-luvundigitoidut-lehdet-asiakaskayttoon $>$ (accessed I 5.I0.202I).

USHMM. 202 I. 'Selected records from the Kansallisarkisto (Finnish National Archive)', United States Holocaust Memorial Museum, $<$ https://collections.ushmm.org/search/ catalog/irn 5 I6686> (accessed I 5.I0.202 I).

Yerusha. 202 I , 'National Archives of Finland', Yerusha: European Jewish Archives Portal, $<$ https://yerusha.eu/network/nationalarchives-of-finland/> (accessed I 5.9.202 I).

\section{Norway}

Center for Studies of Holocaust and Minorities in Norway, 'Arkivet etter Ruth Maier' (The archives of Ruth Maier), <https://www. hlsenteret.no/dokumentasjon/samlinger/ arkivet-etter-ruth-maier.html> (accessed 24. I0.202 I).

Center for Studies of Holocaust and Minorities in Norway, 'Arkivet etter Robert Savosnick innlemmes i Norges dokumentarv' (The archives of Robert Savosnick), <https://www. hlsenteret.no/aktuelt/nyheter/2020/arkivetetter-robert-savosnick-innlemmes-i-norges-. html> (accessed 24.10.202I).

Digitalarkivet, 'Adressebøker', <https://www. digitalarkivet.no/search/sources? $\mathrm{s}=\&$ from $=$ $\&$ to $=\&$ format $=$ all \&st $\%{ }_{5} \mathrm{~B} \%{ }_{5} \mathrm{D}=\mathrm{ADBO}>$ (accessed 24.10.202I).

Digitalarkivet, 'Ruth Maiers arkiv', <https:// www.digitalarkivet.no/search $/$ sources? $\mathrm{s}=\&$ from $=\&$ to $=\&$ format $=$ all $\& \mathrm{a} \%{ }_{5} \mathrm{~B} \%{ }_{5} \mathrm{D}=$ no- $^{-}$ XXXX_arkiv_oooooooooog6\&archive_key=> (accessed 24.10.202 I)

Komissar, Tine, and Vibeke Kieding Banik. 202 I. E-mail correspondence I7.8.202 I. 
National Archives of Norway, 'Public censuses', $<$ https://www.arkivverket.no/en/findyour-ancestors/public-censuses $>$ (accessed 24.10.202 I).

National Library of Norway, 'Adressebøker I 883-r 988', <https://www.nb.no/samlingen/ tidsskrift/adresseboker/ $>$ (accessed 24.IO.202 I).

Oslo City Archives, 'Folketellinger', Oslo City Archives, <https://www.oslo.kommune.no/ $\mathrm{OBA} /$ folketellinger/index.html> (accessed 24.I0.202 I).

Oslo Jewish Museum, 'Samlinger og arkiv', <https://www.jodiskmuseumoslo.no/ samlinger-og-arkiv> (accessed I7.8. 202 I).

\section{Sweden}

Digital Archives. 2021. 'ArkivDigital', <https:// www.arkivdigital.net> (accessed 22.I0.202 I).

Digital Museum. 202 r. 'DigitaltMuseum', $<$ https://digitaltmuseum.se $>$ (accessed I 8.IO.2 I)

Lund University Library. $202 \mathrm{I}$. 'Witnessing genocide', <https://www.ub.lu.se/en/ witnessing-genocide> (accessed I 8.10.202I).

National Archives. 202 I. 'Nationell ArkivDatabas (NAD)', <https://sok.riksarkivet.se/nad> (accessed I8.10.202 I).

National Library of Sweden. 202 r. 'Arken', $<$ https://arken.kb.se> (accessed I8.10.202I).

\section{Literature}

Andersson, Lars M. 200o. En jude är en jude är en jude... Representationer av "Juden" i svensk skämtpress omkring 1900-1930 (Lund: Nordic Academic Press).

Bachner, Henrik. I999. Atterkomsten. Antisemitism i Sverige efter 1945 (Stockholm: Natur \& Kultur).

- 2009. "Judefrägan": debatt om antisemitism i 1930-talets Sverige (Stockholm: Atlantis).

Bak, Sofie Lene. 20 I r. Nothing to Speak of: Wartime Experiences of the Danish Jerws 1943-1945 (Copenhagen: The Danish Jewish Museum).

- 201 2. Da krigen var forbi. De danske joders hjemkomst efter besattelsen (Copenhagen: Gyldendal).

Banik, Vibeke Kieding, and Laura Ekholm. 2019. 'Culture, context, and family networks: values and knowledge transfers among Eastern European Jews in the Nordic countries, I880-1940', in Families, Values, and the
Transfer of Knowledge in Northern Societies, 1500-2000, eds. Ulla Aatsinki, Johanna Annola, and Mervi Kaarninen (New York: Routledge), I 20-4I.

Berggren, Elise, Bjarte Bruland, and Mats Tangestuen. 2020. Rapport frå ein gjennomgang av Hva visste hjemmefronten (Oslo: Dreyer).

Blomqvist, Håkan. 2006. Nation, ras och civilisation i svensk arbetarrörelse före nazismen (Stockholm: Carlsson).

Carlsson, Carl Henrik. 2004. Medborgarskap och diskriminering. Östjudar och andra invandrare i Sverige, 1860-1920, Acta Universitatis Upsaliensis (Uppsala universitet).

-2021 Ia. Judarnas historia i Sverige (Stockholm: Natur och kultur).

- 202 rb. 'Judarnas historia i Halmstad', in Moderniteten som framgaing och strategi. En vänbok till Lars $M$ Andersson om ett föränderligt 1900-tal, eds. Mattias Hessérus, Karin Kvist Geverts, Pontus Rudberg, and Malin Thor Tureby (Lund: Nordic Academic Press), 5 I-64.

- 2022 (forthcoming). Källor till judarnas bistoria i Sverige (Stockholm: Riksarkivet).

Czimbalmos, Mercédesz, and Dóra Pataricza. 2019. 'Suomen juutalaisyhteisö suurennuslasin alla - etnografista ja arkistotutkimusta suomenjuutalaisista', Hakebila 2: 27-30.

Dahl, Izabela A. 202 r. 'Witnessing the Holocaust: Jewish experiences and the collection of the Polish Source Institute in Lund', in Early Holocaust Memory in Sweden: Archives, Testimonies and Reflections, eds. Johannes Heuman and Pontus Rudberg (London: Palgrave Macmillan), 67-9r.

Ekholm, Laura. 201 3. Boundaries of an Urban Minority: The Helsinki Jerwish Community from the End of Imperial Russia until the 1970s (Department of Political and Economic Studies, University of Helsinki).

Følner, Bjarke. 20 I r. 'Dansk Jødisk Museums samling - en præsentation', in Dansk Jødisk Historie i 2. Verdenskrigs epoke. En antologi, eds. Sofie Lene Bak, Pia Andersen Høg, Bjarke Følner and Janne Laursen (Copenhagen: The Danish Jewish Museum), I2-2 I.

Hallberg, Lars. 200 I. Källor till invandringens bistoria i statliga myndigheters arkiv 1840 1990 (Stockholm: Riksarkivet).

Harviainen, Tapani. I998. 'Juutalaiset Suomessa', in Juutalainen kulttuuri, eds. Tapani Harviainen and Karl-Johan Illman (Helsinki: Otava), $29 \mathrm{I}-304$. 
Harviainen, Tapani, and Karl-Johan Illman (eds.). I 998. Juutalainen kulttuuri (Helsinki: Otava).

Helsingin Sanomat. 1998. 'Suomen juutalaisten arkisto avataan tänään tutkijoille', Helsingin Sanomat I 9.IO.I 998, <https://www.hs.fi/ kotimaa/art-2000003752538.html> (accessed I 5.9.202 I).

Heß, Cordelia. 202 I. The Medieval Archive of Antisemitism in Nineteenth-Century Sweden: Religious Minorities in the North (Berlin: De Gruyter).

Heuman, Johannes, and Pontus Rudberg (eds). 202 I. Early Holocaust Memory. Archives, Testimonies and Reflections (London: Palgrave Macmillan).

Jansson, Eva-Maria. 2018a. 'The Judaica Collection',_Det Kg1 Bibliotek, <http:// www5.kb.dk/en/nb/samling/js/index.html> (accessed 27.6.202I).

- 20r 8b. 'David Simonsen: Rabbi, scholar, bibliophile and philantropist', Det Kgl. Bibliotek, <http://www5.kb.dk/en/ $\mathrm{nb} /$ samling/js/DSintro.html> (accessed $27.6 .202 \mathrm{I}$ ).

Johannesson, Lena. I988. 'Schene rariteten'. Antisemitisk bildagitation i svensk rabulistpress i 845-I860', in Judiskt liv i Norden, eds. Gunnar Broberg, Harald Runblom and Mattias Tydén (Uppsala universitet), I 79-207. Johansson, Britta (ed.). 2000. Judiska minnen. Berättelser från förintelsen (Stockholm: Nordiska museet).

Kvist Geverts, Karin. 2008. Ett främmande element i nationen. Svensk flyktingpolitik och de judiska fyktingarna 1938-1944, Studia historica Upsaliensia (Uppsala universitet).

Lausten, Martin Schwarz. I 992. Kirke og synagogue 1100-1700. Holdninger i den danske kirke till jødedom og jøder i midderalderen, reformationstiden og den lutherske ortodoksi (Copenhagen: Akademisk Forlag).

-2000. De fromme og joderne. Holdninger til jødedom og joder i Danmark i pietismens tid (1700-1760) (Copenhagen: Akademisk Forlag).

- 2002. Oplysning $i$ kirke og synagoge. Forboldet mellem kristne og joder $i$ den danske Oplysningstid (1760-1814) (Copenhagen: Akademisk Forlag).

- 2005. Frie jøder? Forholdet mellem kristne og jøder i Danmark fra Fribedsbrevet 1814 til Grundloven 1849 (Copenhagen: Anis).

-2007a. Folkekirken og jøderne. Forholdet mellem kristne og joder i Danmark fra 1849 til begyndelsen af det 20. årbundrede (Copenhagen: Anis).

- 2007b. Jodesympati og jodehad i folkekirken. Forholdet mellem kristne og joder i Danmark fra begyndelsen af det 20. årbundrede til 1948 (Copenhagen: Anis).

Lööw, Heléne. 1998. Nazismen i Sverige 19801997. Den rasistiska undergroundrörelsen: musiken, myterna, riterna (Stockholm: Ordfront).

- 201 5. Nazismen i Sverige 2000-2014

(Stockholm: Ordfront).

Maier-Wolthausen, Clemens. 2019. Zuflucht im Norden: Die schwedischen Juden und die Flüchtlinge 1933-1941 (Göttingen: Wallstein Verlag).

Michelet, Marte. 2018. Hva visste hjemmefronten. Holocaust i Norge: varslene, unnvikelsene, hemmeligholdet (Oslo: Gyldendal).

- 202 I. Tilsvar. Svar på motboken til Hva visste hjemmefronten (Oslo: Gyldendal).

Muir, Simo. 2004. Yiddish in Helsinki: Study of a Colonial Yiddish Dialect and Culture (Helsinki: Finnish Oriental Society).

- 2005. 'Tunnistatko? Suomen juutalaisten arkiston upea valokuvakokoelma', Hakebila 3:23.

- 2010. 'Yksityisarkistot kiinnostavat', Hakebila 2: 30.

—. 20 I r. 'Höstvisan löysi tiensä Kansallisarkistoon', Hakehila 2: 30.

Nordisk Judaistik $30(\mathrm{I}), 2019$. 'Boundaries of Jewish Identities in Contemporary Finland', guest editors Mercédesz Czimbalmos and Dóra Pataricza, doi: <https://journal.fi/nj/ issue/view/5635>.

Nyman, Magnus. I 988. Press mot fribeten. Opinionsbildning $i$ de svenska tidningarna och àsiktsbrytningar om minoriteter 1772-1786 (Uppsala universitet).

Rosengren, Henrik. 2013. "'A Wagner for the Jews”: Moses Pergament, Richard Wagner and antisemitism in Swedish cultural life in the interwar period', Scandinavian Journal of History 38(2): 245-6r.

Rudberg, Pontus. 2017. The Swedish Jerws and the Holocaust (London: Routledge).

- 2020. 'Källor till Förintelsens historia i svenska arkiv', in Sveriges museum on Förintelsen, Statens Offentliga utredningar, SOU 2020: 2I (Stockholm: Norstedts juridik).

Rünitz, Lone. 2000. Danmark og de jødiske fygtninge 1933-1940. En bog om flygtninge og menneskerettigheder (Copenhagen: Museum Tusculanum Press). 
2005. Af hensyn til konsekvenserne. Danmark og fygtningesporgsmålet 1933-1940 (Odense: Syddansk Universitetsforlag).

Søbye, Espen. 202 I. Hva vet historikerne. Om hjemmefronten og deportasjonen av jodene. (Oslo: Press).

Sørensen, Øystein, and Kjetil Braut Simonsen (eds.). 2020. Historie og moral. Nazismen, jødene og hjemmefronten (Oslo: Dreyer).

Svenstrup, Thyge, and Vello Helk. I993. Det Mosaiske Troessamfund i København med nedlagte troessamfund i provinsen: Privatarkivregistratur nr. 10.411 (Copenhagen: Rigsarkivet).

Thor Tureby, Malin. 2o I9. 'Svenskjudiska liv. Levnadsberättelser i skuggan av Förintelsen', Svenska landsmål och svenskt folkliv. Tidskrift for talspråksforskning, folkloristik och kulturbistoria I4I: I I 7-45.

Thor Tureby, Malin, and Kristin Wagrell. $2020 a$. Vittnesmål från Förintelsen och de överlevandes berättelser. Definitioner, insamlingar och användningar, 1939-2020 (Stockholm: Forum för levande historia).

- 2020b. 'Digitization, vulnerability, and Holocaust collections', in Santander Art and Culture Law Review 6(2): 87-I I 8.

Tydén, Mattias. r988. 'Antisemitism i Sverige I 880-I 930', in Judiskt liv i Norden, Acta Universitatis Upsaliensis (Uppsala universitet), 259-83.

Valentin, Hugo. I924a. Judarnas historia i Sverige (Stockholm: Bonnier).

. I 924 b. Urkunder till judarnas historia $i$ Sverige (Stockholm: Bonnier).

Van Orden Martinez, Victoria. 202 r. 'Witnessing against a divide? An analysis of early Holocaust testimonies constructed in interviews between Jewish and non-Jewish Poles', in Holocaust Studies, vol. ahead-ofprint, no. ahead of print, pp. I-23, doi: <https://www.tandfonline.com/doi/full/ı. Iо 80/17504902.2021.1981627>. 